удК 343.3, 343.352.7

Ю. Н. Румянцева Всероссийский государственный университет юстищии (РПА Минюста России), Иркутский институт (филиал) 2. Иркутск, Российская Федерация

\title{
ЗЛОУПОТРЕБЛЕНИЕ ДОЛЖНОСТНЫМИ ПОЛНОМОЧИЯМИ КАК УГРОЗА БЕЗОПАСНОСТИ ЭКОНОМИЧЕСКОЙ СИСТЕМЫ
}

\begin{abstract}
АНнотАЦИЯ. Проводится анализ трактовки понятия «злоупотребление должностными полномочиями». Исследуется опыт распространения преступлений, связанных со злоупотреблением должностными полномочиями в период с 2013 по 2016 годы в России, Казахстане, Белоруссии и Украине. На основе актуальных статистических данных формируется представление о должностных злоупотреблениях как об угрозе безопасности экономической системы. Подчеркивается необходимость модернизации системы предупредительных мер, как общесоциальных, так и специальных криминологических при борьбе с должностными злоупотреблениями. Антикриминогенная роль конфискации имущества по принципу «in rem» при преступлениях коррупционной направленности представляется автору недостаточно оцененной. Предлагается рассматривать «усиленный» институт конфискации имущества как превентивную меру предупреждения преступности.

кЛюЧЕВЫЕ СлОВА. Должностные преступления; злоупотребление; злоупотребление должностными полномочиями; регламентация ответственности; экономическая система; экономическая безопасность; коррупция; конфискация имущества.

ИНФОРМАЦИЯ О СТАТЬЕ. Дата Поступления 15 июня 2017 г.; дата принятия к печати 11 октября 2017 г.; дата онлайн-размещения 25 октября 2017 г.
\end{abstract}

Yu. N. Rumyantseva

Russian State University of Justice (RLA of Russia's Ministry of Justice), Irkutsk Institute (branch),

Irkutsk, Russian Federation

\section{ABUSE OF OFFICIAL POWER AS A THREAT TO SECURITY OF ECONOMIC SYSTEM}

ABSTRACT. The article makes an analysis of interpreting the concept of «abuse of official power". It examines the experience of proliferating crimes related to abuse of official power in the period from 2013 to 2016 in Russia, Kazakhstan, Belarus and Ukraine. On the basis of the recent statistics, it forms a vision of abuse of power $t$ as a threat to security of the economic system. It emphasizes the need of modernizing the system of preventive measures, both social and special criminological ones in fight against the official abuse. The author apprehends as insufficiently assessed the anti-criminogenic role of confiscating the property according to «in rem" principle in crimes of corruption character. It is offered to consider a "reinforced» institute of property confiscation as a proactive measure of crime prevention.

KEYWORDS. Official abuse power; abuse; abuse of official power; regulation of liability; economic system; economic security.

ARTICLE INFO. Received June 15, 2017; accepted October 11, 2017; available online October 25, 2017.

Безопасность и устойчивость являются важнейшими характеристиками экономической системы, которые определяют способность экономических субъектов к развитию и обеспечению достойных условий жизнедеятельности населения, устранению возникающих угроз.

(C) Ю. Н. Румяниева, 2017

\section{Baikal Research Journal}

электронный научный журнал Байкальского государственного университета 
Экономическую безопасность необходимо рассматривать как взаимосвязанную систему ее различных уровней: международного, национального, регионального, уровня отдельно взятой хозяйственной структуры, личности $[1$, с. 71$]$.

На экономическую безопасность оказывают влияние множество факторов макро- и микросреды. Влияние на безопасность экономических систем такого фактора как коррупционные преступления трудно переоценить, так как коррупция во всех ее проявлениях затрудняет нормальное функционирование общественных институтов, бизнес-структур, препятствует проведению социальных преобразований и повышению эффективности национальной экономики [2, с. 57].

Можно выделить последствия такого влияния:

1. Экономические последствия: растут масштабы теневой экономики, нарушаются конкурентные механизмы рынка, что приводит к уменьшению налоговых поступлений и ослаблению бюджета. Как следствие, государство теряет финансовые рычаги управления экономикой, обостряются социальные проблемы из-за невыполнения бюджетных обязательств, снижается уровень финансовой безопасности государства.

Возникают препятствия для реализации макроэкономической политики государства.

2. Социальные последствия: снижается способность власти решать социальные проблемы, растет имущественное неравенство, дискредитируется право как основной инструмент регулирования жизни государства и общества. В общественном сознании формируется представление о беззащитности граждан как перед преступностью, так и перед лицом власти.

3. Политические последствия: снижается доверие к власти, падает престиж страны на международной арене, растет угроза ее экономической и политической изоляции; возникает угроза разложения демократических институтов.

В свою очередь актуальность изучения должностных злоупотреблений, составляющих основу коррупционных преступлений, как фактора, угрожающего безопасности экономических систем, обусловлена глубокими изменениями экономических условий хозяйствования. Всеохватывающая интеграция, глобализация экономики вызывает необходимость поиска и внедрения новых инновационных методов и подходов обеспечения антикоррупционной, экономической безопасности всего мирового сообщества.

Злоупотребление должностными полномочиями сегодня выступает предметом пристального внимания законодателя и правоприменителей, осуществляющих деятельность по борьбе с коррупционной преступностью в органах власти [3, с. 181; 4, с. 17].

Исследование проблем распространения преступлений, совершаемых путем злоупотребления должностными полномочиями, их квалификации и вопросов предупреждения мы считаем уместным начать с рассмотрения ряда теоретических вопросов.

Для более детального анализа этого явления изначально необходимо дать определение, что же собой представляет злоупотребление вообще.

Словарь русского языка Ожегова С. И. определяет злоупотребление как проступок, состоящий в незаконном, преступном использовании своих прав, возможностей [5, с. 128].

Толковый словарь русского языка под редакцией Д. Н. Ушакова добавляет в трактовку понятия «злоупотребление» - сознательное, незаконное и корыстное использование возможностей и прав во вред другим [6, с. 250].

Статья 301. Модельного Уголовный кодека, рекомендательного законодательного акта для Содружества Независимых Государств (с изменениями на 16 ноября

\section{Baikal Research Journal}

электронный научный журнал Байкальского государственного университета 
2006 года) содержит понятие злоупотребление служебным положением, которое определяется как использование публичным служащим предоставленных ему полномочий, вопреки интересам службы, если оно совершено из корыстной, иной личной или групповой заинтересованности и повлекло существенное нарушение прав и законных интересов граждан, организаций, общества или государств ${ }^{1}$.

УК РФ трактует злоупотребление должностными полномочиями как использование должностным лицом своих служебных полномочий вопреки интересам службы, если это деяние совершено из корыстной или иной личной заинтересованности и повлекло существенное нарушение прав и законных интересов граждан или организаций либо охраняемых законом интересов общества или государства ${ }^{2}$.

Таким образом, основным объектом злоупотребления должностными полномочиями является осуществляемая в соответствии с законом деятельность публичного аппарата власти и управления. В качестве дополнительного объекта выступают конституционные права человека и гражданина, охраняемые законом экономические и иные интересы граждан, организаций и государства [7, с. 71].

Под использованием должностным лицом своих служебных полномочий вопреки интересам служббы понимается совершение действий (либо бездействие), которые хотя и были непосредственно связаны с осуществлением должностным лицом своих прав и обязанностей, однако не вызывались служебной необходимостью и объективно противоречили как общим задачам и требованиям, предъявляемым к государственному аппарату и аппарату органов местного самоуправления, так и тем целям и задачам, для достижения которых должностное лицо было наделено соответствующими должностными полномочиями ${ }^{3}$.

Для дальнейшего анализа природы должностных злоупотреблений следует учитывать опыт и тенденции применения этого института в разных странах. Анализ уголовного законодательства стран «бывших» республик СССР (Украина, Белоруссия, Казахстан) удобно представить в таблице.

\section{Некоторые особенности законодательной регламентации ответственности} за злоупотребление должностными полномочиями

\begin{tabular}{|c|c|c|c|c|}
\hline \begin{tabular}{|} 
Норма- \\
тивный \\
акт/ Дис- \\
позиция/ \\
Санкшия
\end{tabular} & УК Белоруссии & УК Украины & УК Казахстана & УК России \\
\hline $\begin{array}{l}\text { Диспози- } \\
\text { ция }\end{array}$ & $\begin{array}{l}\text { Статья } 424 . \\
\text { Злоупотребле- } \\
\text { ние властью или } \\
\text { служебными } \\
\text { полномочиями: } \\
\text { умышленное во- } \\
\text { преки интересам } \\
\text { службы совер- } \\
\text { шение должност- } \\
\text { ным лицом из } \\
\text { корыстной }\end{array}$ & $\begin{array}{l}\text { Статья 364. Злоу- } \\
\text { потребление вла- } \\
\text { стью или служеб- } \\
\text { ным положением: } \\
\text { умышленное, из } \\
\text { корыстных по- } \\
\text { буждений либо } \\
\text { в иных личных } \\
\text { интересах или в } \\
\text { интересах третьих } \\
\text { лиц, использование }\end{array}$ & $\begin{array}{l}\text { Статья 361. Злоупо- } \\
\text { требление должност- } \\
\text { ными полномочиями: } \\
\text { использование лицом, } \\
\text { уполномоченным на } \\
\text { выполнение государ- } \\
\text { ственных функций, } \\
\text { либо приравненным к } \\
\text { нему лицом своих слу- } \\
\text { жебных полномочий } \\
\text { вопреки интересам }\end{array}$ & $\begin{array}{l}\text { Статья 285. Зло- } \\
\text { употребление } \\
\text { должностными } \\
\text { полномочиями: ис- } \\
\text { пользование долж- } \\
\text { ностным лицом } \\
\text { своих служебных } \\
\text { полномочий во- } \\
\text { преки интересам } \\
\text { службы, если это } \\
\text { деяние соверше- } \\
\text { но из корыстной } \\
\text { или иной личной }\end{array}$ \\
\hline
\end{tabular}

${ }^{1}$ Модельный Уголовный кодекс : рекомендат. законодат. акт для СНГ от 17 февр. 1996 г. № 7-5 : (в ред. от 16 нояб. 2006). URL: http://docs.cntd.ru/document/901781490.

2 Уголовный кодекс Российской Федерации : федер. закон от 13 июня 1999 г. № 63-ФЗ : (в ред. от 19 дек. 2016) // Российская газета. 1996. 18 июня.

${ }^{3}$ Бриллиантов А. В. Комментарий к Уголовному кодексу Российской Федерации : в 2 т. М., 2015. 792 c.

\section{Baikal Research Journal}


Окончание таблицы

\begin{tabular}{|c|c|c|c|c|}
\hline \begin{tabular}{|l|} 
Норма- \\
тивный \\
акт/ Дис- \\
позиция/ \\
Санкция
\end{tabular} & УК Белоруссии & УК Украины & УК Казахстана & УК России \\
\hline $\begin{array}{l}\text { Диспози- } \\
\text { ция }\end{array}$ & $\begin{array}{l}\text { или иной личной } \\
\text { заинтересован- } \\
\text { ности действий с } \\
\text { использованием } \\
\text { своих служебных } \\
\text { полномочий }\end{array}$ & $\begin{array}{l}\text { служебным лицом } \\
\text { власти или служеб- } \\
\text { ного положения } \\
\text { вопреки интересам } \\
\text { службы, если оно } \\
\text { причинило суще- } \\
\text { ственный вред ох- } \\
\text { раняемым законом } \\
\text { правам, свободам и } \\
\text { интересам отдель- } \\
\text { ных граждан или } \\
\text { государственным } \\
\text { или общественным } \\
\text { интересам, или } \\
\text { интересам юриди- } \\
\text { ческих лиц } \\
\end{array}$ & $\begin{array}{l}\text { службы в целях } \\
\text { извлечения выгод } \\
\text { и преимуществ для } \\
\text { себя или других лиц } \\
\text { или организаций } \\
\text { либо нанесения вреда } \\
\text { другим лицам или ор- } \\
\text { ганизациям, если это } \\
\text { повлекло причинение } \\
\text { существенного вреда } \\
\text { правам и законным } \\
\text { интересам граждан } \\
\text { или организаций либо } \\
\text { охраняемым законом } \\
\text { интересам общества } \\
\text { или государства }\end{array}$ & $\begin{array}{l}\text { заинтересованности } \\
\text { и повлекло су- } \\
\text { щественное нару- } \\
\text { шение прав и за- } \\
\text { конных } \\
\text { интересов граждан } \\
\text { или организаций } \\
\text { либо охраняемых } \\
\text { законом интересов } \\
\text { общества или госу- } \\
\text { дарства }\end{array}$ \\
\hline $\begin{array}{l}\text { Макси- } \\
\text { мальная } \\
\text { санкция }\end{array}$ & $\begin{array}{l}\text { лишение сво- } \\
\text { боды от трех } \\
\text { до десяти лет с } \\
\text { конфискацией } \\
\text { имущества или } \\
\text { без конфиска- } \\
\text { ции, лишение } \\
\text { права занимать } \\
\text { определенные } \\
\text { должности или } \\
\text { заниматься опре- } \\
\text { деленной дея- } \\
\text { тельностью }\end{array}$ & $\begin{array}{l}\text { лишение свободы } \\
\text { на срок трех лет } \\
\text { со штрафом от } \\
\text { пятисот до одной } \\
\text { тысячи необлага- } \\
\text { емых минимумов } \\
\text { доходов граждан }\end{array}$ & $\begin{array}{l}\text { лишение свободы от } \\
\text { четырех до восьми лет } \\
\text { с конфискацией иму- } \\
\text { щества, с пожизнен- } \\
\text { ным лишением права } \\
\text { занимать определен- } \\
\text { ные должности или } \\
\text { заниматься определен- } \\
\text { ной деятельностью6 }\end{array}$ & $\begin{array}{l}\text { лишение свободы на } \\
\text { срок до десяти лет } \\
\text { с лишением права } \\
\text { занимать опреде- } \\
\text { ленные должности } \\
\text { или заниматься } \\
\text { определенной дея- } \\
\text { тельностью на срок } \\
\text { до трех лет }\end{array}$ \\
\hline
\end{tabular}

Данный анализ выявил значительное сходство в подходах законодателей и позволил автору прийти к выводу о том, что признаки объективной и субъективной стороны основного состава злоупотребления должностными полномочиями в большинстве уголовных кодексов сходны с признаками, установленными ст. 285 УК РФ, но при этом в уголовных кодексах ряда стран им дается законодательная расшифровка [8, с. 48].

Подходы к регламентации ответственности за должностные злоупотребления также представляются схожими для «бывших» союзных республик [9, с. 52]. Так, законодатели в УК Украины, Казахстана и Белоруссии применяют в качестве наказания за злоупотребление должностными полномочиями - лишение свободы, конфискацию имущества, лишение права занимать определенные должности или заниматься определенной деятельностью.

Нисколько не умоляя теоретические изыскания в трактовке того или иного явления, установления взаимосвязей и противоречий современного общества, по

${ }^{4}$ Уголовный кодекс Республики Беларусь закон Республики Беларусь от 9 июля 1999 г. : (в ред. от 19 июля 2016) // Национальный правовой Интернет-портал Республики Беларусь. URL: http:// etalonline.by $/$ ?type=text\&regnum $=$ HK9900275\#load_text_none_1_.

${ }^{5}$ Уголовный кодекс Украины : закон от 05 апр. 2001 г. № 2341-III : (в ред. от 6 окт. 2016) // Законодательство Украины. URL: http://meget.kiev.ua/kodeks/ugolovniy-kodeks/razdel-1-17/.

${ }_{6}^{6}$ Уголовный кодекс Республики Казахстан : закон Республики Казахстан от 3 июля 2014 г. № 226-V ЗРК : (в ред. от 22 дек. 2016) // Казахстанская правда. 2014. 09 июля.

\section{Baikal Research Journal}


мнению автора, их рассмотрение будет не полным без анализа практики распространения исследуемого уголовно-наказуемого деяния.

Согласно статистическим данным, опубликованным Генеральной Прокуратурой РФ по состоянию на 1 января 2017 года в РФ зарегистрировано 2273 преступления по ст. 285 - злоупотребление должностными полномочиями. При этом последние три года (данные с 2013 по 2016 год) наблюдается незначительное изменение количества зарегистрированных преступлений по данной статье ${ }^{7}$.

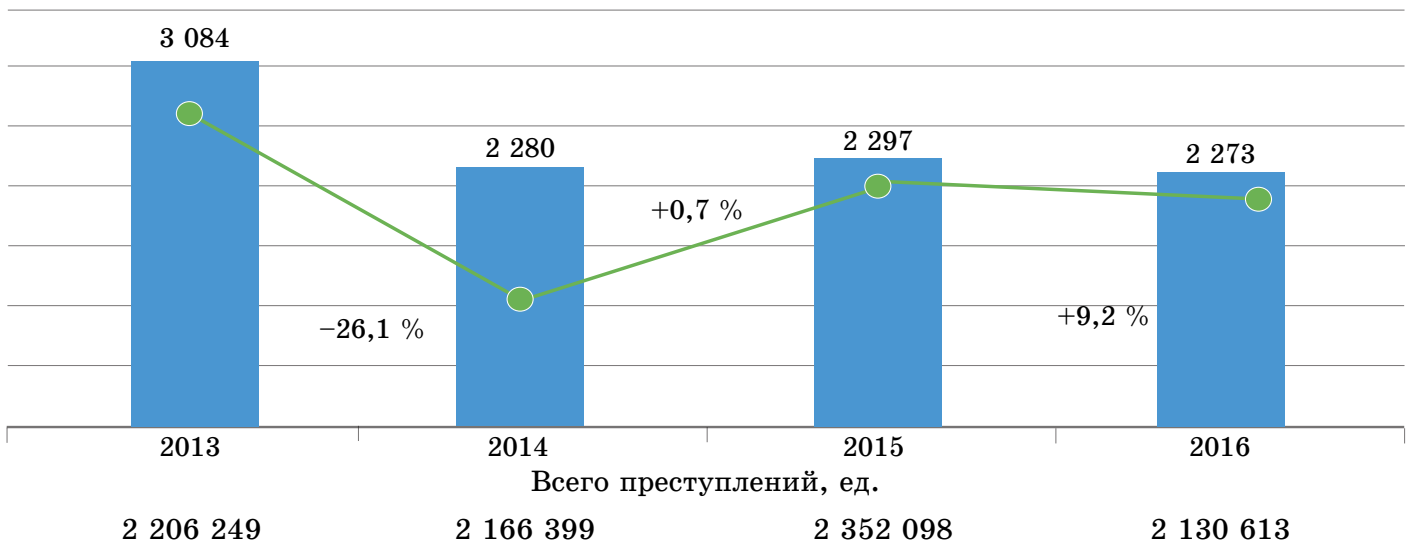

Рис. 1. Количество зарегистрированных преступлений по ст. 285 Злоупотребление должностным полнолочияли УК России в период с 2013 по 2016 г2.

Согласно статистическим данным, опубликованным Министерством внутренних дел республики Беларусь по состоянию на 1 января 2017 года в республике зарегистрировано 271 преступление по ст. 424. Злоупотребление властью или служебными полномочиями. При этом в течение исследуемого период (2013-2016 годы) общее количество зарегистрированных преступлений по данной статье изменяется незначительно ${ }^{8}$.

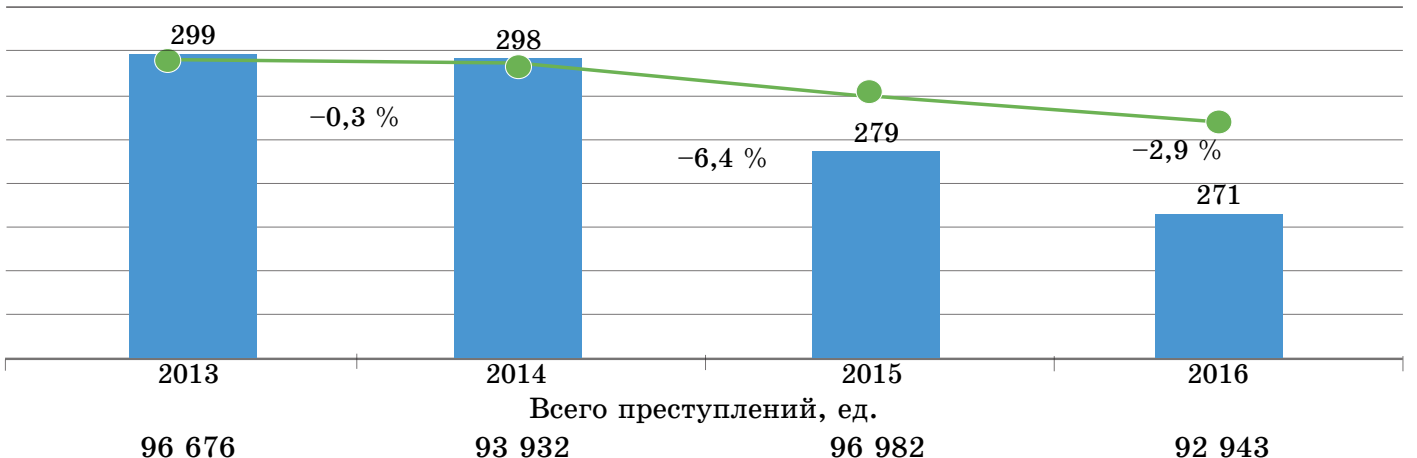

Рис. 2. Количество преступлений по ст. 424. Злоупотребление властью или служебныли полномочияли УК Белоруссии в период с 2013 по 2016 г2.

${ }^{7}$ Портал правовой статистики Генеральной прокуратуры РФ // Генеральная прокуратура РФ. M., 2017. URL: http://crimestat.ru.

8 Общая статистика // МВД Республики Белоруссии. Минск, 2017. URL: http://mvd.gov.by/ main.aspx?guid=253173.

\section{Baikal Research Journal}


Согласно статистическим данным, опубликованным Генеральной Прокуратурой Украины по состоянию на 1 января 2017 года в республике зарегистрировано 3360 преступлений по ст. 364. Злоупотребление властью или служебным положением. При этом, начиная с 2014 года наблюдается значительный рост количества зарегистрированных преступлений по данной статье ${ }^{9}$.

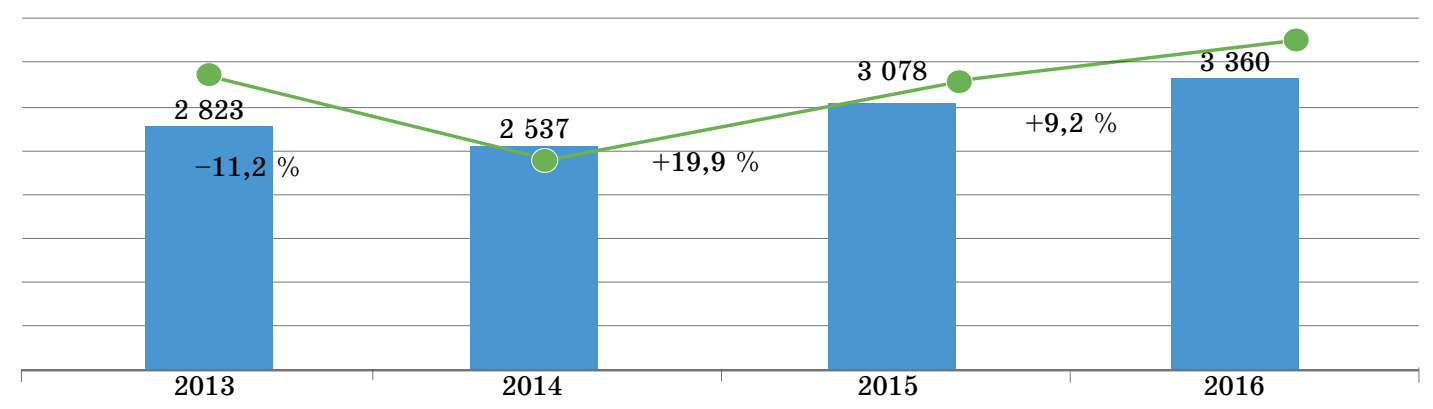

Всего преступлений, ед.

563560

529139

565182

592604

Рис. 3. Количество зарегистрированных преступлений по $\mathrm{cm}$. 364 . Злоупотребление властью или служебныл положениел УК Украины в период с 2013 по 2016 г2.

Согласно статистическим данным, опубликованным Генеральной Прокуратурой Казахстана по состоянию на 1 января 2017 года в республике зарегистрировано 704 преступлений по ст. 361. Злоупотребление должностными полномочиями. При этом, необходимо отметить, что с начиная с 2014 года наблюдается значительный рост количества зарегистрированных преступлений по данной статье ${ }^{10}$.

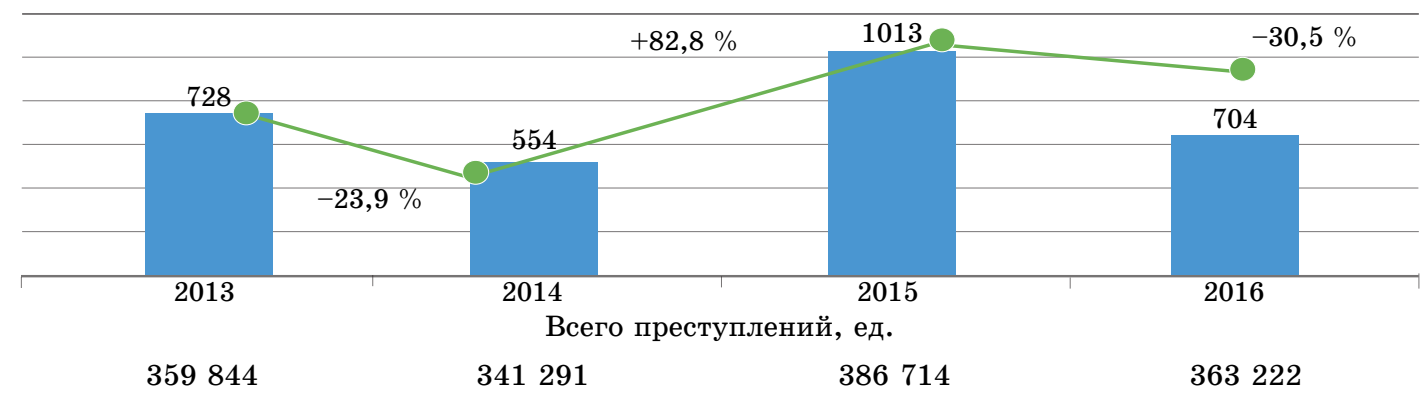

Рис. 4. Количество зарегистрированных преступлений по ст. 361. Злоупотребление должностныли полнолочияли УК Казахстана в период с 2013 по 2016 г2.

Таким образом, несмотря на общность подходов к трактовке самого явления злоупотребления должностными полномочиями на уровне законодательства, ста-

9 Убийственный рост преступности в Украине: причины и последствия // РИА Новости Украины. Киев, 2016. URL: http://rian.com.ua/analytics/20160330/1007549064.html. Статистическая информация // Генеральная Прокуратура Украины. Киев. URL: http://www.gp.gov.ua/ua/stat.html.

${ }^{10}$ Общая статистика / Комитет по правовой статистике и специальным учетам генеральной прокуратуры Республики Казахстан // Генеральная прокуратура Республики Казахстан. Астана, 2017. URL: доступа: http://pravstat.prokuror.kz/rus.

\section{Baikal Research Journal}


тистические данные о практике распространения анализируемых преступных деяний в исследуемых странах разнятся. Имеющиеся данные подтверждают, что должностные злоупотребления следует рассматривать как реальную угрозу безопасности экономических систем указанных государств.

Вместе с тем, полученные цифры говорят об общей тенденции, связанной с увеличением количества регистрируемых преступлений в данной сфере год от года, подтверждая недостаточную эффективность и необходимость модернизации системы предупредительных мер, как общесоциальных, так и специальных криминологических.

Представляется, что изменения диспозиций статей и санкций, предусмотренных за злоупотребление должностными полномочиями, не являются ключевыми в данном вопросе, объектом внимания должно стать функционирование «сопутствующих» институтов, отдельных элементов, образующих систему в целом.

Так, подобно изменениям в уголовном законе, связанным с практическим применением института принудительных работ, по мнению автора, следует вернуться к вопросу конфискации имущества в России, которая применяется лишь в качестве иных мер уголовно-правового характера на основании обвинительного приговора (ст. 104.1 УК РФ), недооценка ее антикриминогенной роли являются определенно необоснованной.

Являясь «приложением» к наказанию, конфискация фактически преследует или, по крайней мере, должна преследовать и его цели, направленные на предупреждение преступлений, связанных с должностными злоупотреблениями. Кроме того, в научной литературе отмечается возможная эффективность данного института и при предупреждении иных преступлений, в частности, против налоговой системы [10, с. 480].

В большинстве случаев обвиняемые предстают перед судом, практически ничего не имея в собственности. Все имущество, как правило, ими заранее оформлено на родственников либо на доверенных лиц. К сожалению, законодательством Российской Федерации не предусмотрена возможность конфискации имущества у родственников преступника [11, с. 8; 12, с. 518].

Законодатель ограничился лишь формулировкой о том, что подлежит конфискации также имущество у лица, которое знало или должно было знать, что оно получено в результате преступных действий. Фактически данная норма позволяет органам следствия и прокуратуры обращать взыскания в отношении денег и имущества в случае, когда владелец не может доказать законность их происхождения.

То есть данной нормой фактически предусматривается конфискация «іn rem», которая активно используется в мире. Однако, практика применения данного института при расследовании резонансных уголовных дел, пока выглядит противоречиво.

Фактическое применение института конфискации «in rem» как превентивная мера уголовно-правового характера, выраженная в форме конфискации всех видов и форм похищенного имущества у коррупционера, как носителя опасных криминальных тенденций, вполне соответствует указанной цели [13, с. 165], специфике юридической природы злоупотребления должностными полномочиями, и, следовательно, позволит повысить эффективность борьбы с преступлениями в данной сфере.

\section{Список использованной литературы}

1. Агильдин В. В. Институт конфискации имущества как превентивная мера предупреждения преступности / В. В. Агильдин // Криминологический журнал Байкальского государственного университета экономики и права. - 2013. — № 1. - С. 71-75.

\section{Baikal Research Journal}

электронный научный журнал Байкальского государственного университета 
2. Мусаелян М. Ф. Совершенствование уголовной политики в сфере противодействия коррупции в Российской Федерации // Журнал российского права. - 2014. — № 5. — С. 56-66.

3. Казанцева Е. Г. Проблемы экономической безопасности региона и пути их решения (на примере Кировской области) / Е. Г. Казанцева // Экономика региона. — 2009 - № 2. C. $180-191$.

4. Волженкин Б. В. Служебные преступления / Б. В. Волженкин. - М. : Юристъ, 2000. -368 c.

5. Ожегов С. И. Словарь русского языка: Ок. 53000 слов / С. И. Ожегов ; под общ. ред. Л. И. Скворцова. - 24-е изд., испр. - М. : Оникс, 2007. - 1200 с.

6. Толковый словарь русского языка. В 4 т. / под ред. Д. Н. Ушакова. - М. : Советская энциклопедия, 1935-1940. - 4 т.

7. Богдановская В. А. Актуальные проблемы реформы уголовного законодательства России / В. А. Богдановская // Вопросы российского и международного права. — 2012. № 5-6. - С. 70-82.

8. Ответственность за должностные преступления в зарубежных странах / отв. ред. Ф. М. Решетников. - М. : Юрид. лит., 1994. - 128 с.

9. Бриллиантов А. В. Должностное лицо в уголовном законодательстве России и зарубежных стран / А. В. Бриллиантов, Е. Ю. Четвертакова. - М. : Проспект, 2014. - 192 с.

10. Середа И. М. Совершенствование назначения и исполнения уголовного наказания за преступления против налоговой системы / И. М. Середа // Всероссийский криминологический журнал. - 2016. - Т. 10, № 3. - С. 480-486.

11. Конов Т. Х. Позитивное воздействие на злоупотребление должностными полномочиями: социальный и правовой аспекты : автореф. дис. ... канд. юрид. наук: 12.00.08/ Т. Х. Кононов. - Саратов, 2012. - 22 с.

12. Теоретические основы предупреждения преступности на современном этапе развития российского общества / под ред. Р. В. ЖЖубрина. - М. : Проспект, 2016. - 656 с.

13. Головненков П. В. Сущность конфискации имущества в германском и российском уголовном праве / П. В. Головненков, Т. Г. Понятовская // Криминологический журнал Байкальского государственного университета экономики и права. - 2015. — Т. 9, № 1 . C. 164-173. - DOI: 10.17150/1996-7756.2015.9(1).164-173.

\section{References}

1. Agildin V. V. Institution of property confiscation as a proactive measure of crime prevention. Kriminologicheskii zhurnal Baikal'skogo gosudarstvennogo universiteta ekonomiki $i$ prava = Criminological Journal of Baikal State University of Economics and Law. 2013, no. 1, pp. 71-75. (In Russian).

2. Musaelyan M. F. Improving criminal policy in sphere of corruption counteraction in the Russian Federation. Zhurnal rossiiskogo prava = Journal of Russian Law. 2014, no. 5, pp. 56-66. (In Russian).

3. Kazantseva E. G. Problems of regional security and ways of their solution (in terms of Kirov Oblast). Ekonomika regiona = Regional Economy. 2009, no. 2, pp. 180-191. (In Russian).

4. Volzhenkin B. V. Sluzhebnye prestupleniya [Abuse of Office]. Moscow, Yurist" Publ., 2000. $368 \mathrm{p}$.

5. Ozhegov S. I.; Skvortsova L. I. (ed.). Slovar' russkogo yazyka [The Dictionary of the Russian Language]. 24 ${ }^{\text {nd }}$ ed. Moscow, Oniks Publ., 2007. 1200 p.

6. Ushakov D. N. Tolkovyi slovar' russkogo yazyka [The Explanatory Dictionary of the Russian Language]. Moscow, Sovetskaya entsiklopediya Publ., 1935-1940, vol. 1-4.

7. Bogdanovskaya V. A. Topical problems of reforming Russia's criminal legislation. Voprosy rossiiskogo $i$ mezhdunarodnogo prava $=$ Issues of Russian and International Law. 2012, no. 5-6, pp. 70-82. (In Russian).

8. Reshetnikov F. M. (ed.). Otvetstvennost' za dolzhnostnye prestupleniya $v$ zarubezhnykh stranakh [Responsibility for official crimes in foreign countries]. Moscow, Yuridicheskaya literatura Publ., 1994. $128 \mathrm{p}$.

9. Brilliantov A. V., Chetvertakova E. Yu. Dolzhnostnoe litso v ugolovnom zakonodatel'stve Rossii $i$ zarubezhnykh stran [Office holder in criminal legislation of Russia and foreign countries]. Moscow, Prospekt Publ., 2014. 192 p.

\section{Baikal Research Journal}


9. Sereda I. M. Improving imposition and execution of criminal punishment for crimes against taxation system. Vserossiiskii kriminologicheskii zhurnal = Russian Journal Of Criminology. 2016, vol. 10, no. 3, pp. 480-486. (In Russian).

10. Konov T. Kh. Pozitivnoe vozdeistvie na zloupotreblenie dolzhnostnymi polnomochiyami: sotsial'nyi i pravovoi aspekty. Avtoref. Kand. Diss. [Positive impact on abuse of official power: social and legal aspects. Cand. Diss. Thesis]. Saratov, 2012. 22 p.

11. Zhubrin R. V. (ed.). Teoreticheskie osnovy preduprezhdeniya prestupnosti na sovremennom etape razvitiya rossiiskogo obshchestva [heoretical basics of crime prevention at the present stage of Russian society“ development]. Moscow, Prospekt Publ., 2016. 656 p.

12. Golovnenkov P. V., Ponyatovskaya T. G. Essence of property confiscation in $\mathrm{m}$ German and Russian criminal law. Kriminologicheskii zhurnal Baikal'skogo gosudarstvennogo universiteta ekonomiki i prava = Criminological Journal of Baikal State University of Economics and Law 2015, vol. 9, no. 1, pp. 164-173. (In Russian).

\section{Информация об авторе}

Рулянцева Юлия Николаевна - доцент кафедры государственно-муниципального управления и предпринимательского права Всероссийского государственного университета юстиции (РПА Минюста России), Иркутского института (филиала), кандидат экономических наук; 664011, г. Иркутск, ул. Некрасова, д. 4, e-mail: ynrumyantseva@mail.ru.

\section{Author}

Yuliya N. Rumyantseva - PhD in Economics, Associate Professor, Chair of Governmental and Municipal Management and Business Law, All-Russian State University of Justice (RLA of Russia's Ministry of Justice), Irkutsk Institute (branch); 4 Nekrasov St., 664011, Irkutsk; e-mail: ynrumyantseva@mail.ru.

\section{Для цитирования}

Румянцева Ю.Н. Злоупотребление должностными полномочиями как угроза безопасности экономической системы/ Ю. Н. Румянцева // Baikal Research Journal. — 2017. - T. 8, № 3. - DOI : 10.17150/2411-6262.2017.8(3).20.

\section{For Citation}

Rumyantseva Yu. N. Abuse of official power as a threat to security of economic system. Baikal Research Journal, 2017, vol. 8, no. 3. DOI: 10.17150/2411-6262.2017.8(3).20. (In Russian).

\section{Baikal Research Journal}

